\title{
The Impact of Coronavirus Disease-2019 on Men with Primary Infertility: Case Report
}

\author{
(D) Ahmet Salvarci1, (D) Ali Sami Gurbuz², (D) Fuat Ali3 \\ ${ }^{1}$ Novafertile and Medicana Hospital IVF Centers, Medicana Hospital Affiliated with KTO Medical Faculty, Department of Urology, Konya, Turkiye \\ 2Novafertile and Medicana Hospital IVF Centers, Medicana Hospital Affiliated with KTO Medical Faculty, Department fo Obstetrics and \\ Gynecology, Konya, Turkiye \\ ${ }^{3}$ Novafertile IVF Centers, Department of Obstetrics and Gynecology, Konya, Turkiye
}

\begin{abstract}
At present, the world is faced with the coronavirus disease-2019 (COVID-19) threat caused by another novel coronavirus, the severe acute respiratory syndrome coronavirus 2. A 29-year-old patient diagnosed with primary infertility had COVID-19. Temporary severe oligo-astheno-teratozoospermia was observed in the long term; however, permanent losses occurred in rapid progressive sperms. His total testosterone level and total motile sperm count were permanently reduced. Permanent reductions occurred in his testicular volumes. But semen analysis values before COVID-19 was observed again. Pregnancy with intra cytoplasmic sperm injection was achieved with a high fertilization rate.
\end{abstract}

Keywords: COVID-19, infertility, pregnancy

\section{Introduction}

Men are observed to be more affected by the highly contagious coronavirus disease-2019 (COVID-19) caused by severe acute respiratory syndrome-coronavirus-2 (SARS-CoV-2) compared to women (male/ratio rate is 2.7:1) (1). In addition, a negative impact occurs in spermatogenesis and testes (2). The virus is not necessarily directly present to cause harm to the male reproductive system (3). This case provides a chronological presentation of COVID-19 following the diagnosis of primary infertility.

\section{Case Report}

A 29-year-old male patient, with no co-morbidities and who was married for 1.5 years, had been admitted to the emergency department due to a fever at $39{ }^{\circ} \mathrm{C}$, which had persisted for 3 days. The result of the quantitative reverse transcriptasepolymerase chain reaction analysis performed on a pharyngeal swab sample was positive. Laboratory analyses resulted in mild leukopenia of $3.789 / \mathrm{mm}^{3}$, hemoglobin of $14.3 \mathrm{~g} / \mathrm{dL}_{\text {, normal }}$ D-dimer of $0.2 \mathrm{mg} / \mathrm{L}$, and ferritin of $65 / \mu \mathrm{L}$. A urea of $24 \mathrm{mg} /$
$\mathrm{dL}$, creatinine of $1.08 \mathrm{mg} / \mathrm{dL}$, sodium of $138 \mathrm{mg} / \mathrm{dL}$, potassium of $4.01 \mathrm{mEq} / \mathrm{L}$, aspartate aminotransferase of $22 \mathrm{U} / \mathrm{L}$, alanine aminotransferase of $15 \mathrm{U} / \mathrm{L}$, fibrinogen of $352.1 \mathrm{~g} / \mathrm{L}$, total bilirubin of $0.5 \mathrm{mg} / \mathrm{dL}$, and sedimentation of $2 \mathrm{~mm} / \mathrm{h}$ were at a normal level. The C-reactive protein (CRP) was $5.62 \mathrm{mg} / \mathrm{L}$ (normal 5-10 mg/L). Favipiravir and enoxaparin sodium were administered. The semen analyses were evaluated according to the World Health Organization 2010 reference values. The pain was assessed according to the Wong-Baker face pain rating scale. The testes were examined with scrotal ultrasound/Doppler. The patient had oligo-astheno-teratozoospermia before the onset of COVID-19 (Table 1). The patient came to our clinic on day 45 after COVID-19. The semen analysis performed in an external center revealed a severe oligo-astheno-teratozoospermia that has developed on day 22 of COVID-19. Mild pain began on day 22 and intensified on day 49 in both testicles (+). Left testicular volume was lower compared to that of the right testis under ultrasound. The volume reduction in right and left testes occurred as $16.3 / \mathrm{mm}^{3}\left(29.9 / 23.3 \mathrm{~mm}^{3}, 25.41 \%\right)$ and $12.5 /$ $\mathrm{mm}^{3}\left(28.9 / 16.4 \mathrm{~mm}^{3}, 43.25 \%\right)$, respectively, on day 49 (Figure 1). Orchialgia, which woke up the patient and was suppressed with paracetamol, developed on days 60 and 75, but no typical

Correspondence: Ahmet Salvarci MD, Novafertile and Medicana Hospital IVF Centers, Medicana Hospital Affiliated with KTO Medical Faculty, Department of Urology, Konya, Turkiye

Phone: +90 3323215151 E-mail: drsalvarci@hotmail.com ORCID-ID: orcid.org/0000-0002-5231-2415

Received: 03.03.2021 Accepted: 14.05 .2021

Cite this article as: Salvarci A, Gurbuz AS, Ali F. The Impact of Coronavirus Disease-2019 on Men with Primary Infertility: Case Report. J Urol Surg 2021;8(4):306-316

${ }^{\circ}$ Copyright 2021 by the Association of Urological Surgery / Journal of Urological Surgery published by Galenos Publishing House. 
Table 1. Chronological list evaluating the results before and after COVID-19

\begin{tabular}{|c|c|c|c|c|c|c|c|c|c|c|c|c|c|c|}
\hline $\begin{array}{l}2020-2021 \\
\text { year }\end{array}$ & 22.01 & 23.01 & 01.06 & 19.09 & 11.10 & 14.10 .2020 & 3.11 & 4.11 & 7.11 & $18.11 / 3.12$ & 18.12 & $\begin{array}{l}19- \\
23 / 2021\end{array}$ & 4.1.2021 & 17.1.2021 \\
\hline & Before & Before & Before & $\begin{array}{l}\text { Days } \\
1,10,18\end{array}$ & Day 22 & Day 25 & Day 45 & Day 46 & Day 49 & $\begin{array}{l}\text { Days } \\
60,75\end{array}$ & Day 90 & \begin{tabular}{|l|} 
Day \\
91-95
\end{tabular} & Day 108 & Day 113 \\
\hline FSH mIU/L & & 2.42 & & & & & & 2.6 & & & 2.98 & & 2.7 & \\
\hline $\mathrm{LH}$ mIU/L & & 5.46 & & & & & & 4.04 & & & 3.74 & & 3.93 & \\
\hline PRL mIU/L & & 15.77 & & & & & & 8.53 & & & 14.22 & & 9.66 & \\
\hline $\mathrm{E} 2 \mathrm{pg} / \mathrm{mL}$ & & & & & & & & 48.2 & & & & & 33.49 & \\
\hline$\Pi \mathrm{ng} / \mathrm{dL}$ & & 303.57 & & & & & & 395.26 & & & 216.44 & & 173.89 & \\
\hline Volume/mL & 5 & & 4 & & 3.5 & & 4 & & & & 5.2 & & 3.6 & \\
\hline Number/mL & $2.7 \times 10^{6}$ & & $7 \times 10^{6}$ & & $0.6 \times 10^{6}$ & & $4 \times 10^{6}$ & & & & $8 \times 10^{6}$ & & $9 \times 10^{6}$ & \\
\hline Total count & $13.5 \times 10^{6}$ & & $28 \times 10^{6}$ & & $2.1 \times 10^{6}$ & & $16 \times 10^{6}$ & & & & $41 \times 10^{6}$ & & $32.4 \times 10^{6}$ & \\
\hline $\begin{array}{l}\text { Rapidly } \\
\text { progressive } \\
\%\end{array}$ & 24 & & 32 & & 0 & & 0 & & & & 0 & & 0 & \\
\hline $\begin{array}{l}\text { Slowly } \\
\text { progressive } \\
\%\end{array}$ & 0 & & 12 & & 0 & & 0 & & & & 13 & & 33 & \\
\hline $\begin{array}{l}\text { In situ } \\
\text { motile \% }\end{array}$ & 10 & & 56 & & 4 & & 7 & & & & 0 & & 0 & \\
\hline Immotile $\%$ & 66 & & 44 & & 96 & & 93 & & & & 87 & & 67 & \\
\hline $\begin{array}{l}\text { Kruger } \\
\text { normal \% }\end{array}$ & 1 & & 1 & & 0 & & 1 & & & & 1 & & 1 & \\
\hline TMSC & $2.7 \times 10^{6}$ & & $15.7 \times 10^{6}$ & & $0.084 \times 10^{6}$ & & $1.12 \times 10^{6}$ & & & & $5.33 \times 10^{6}$ & & $3.85 \times 10^{6}$ & \\
\hline $\begin{array}{l}\text { Rigth testis/ } \\
\mathrm{mm}^{3}\end{array}$ & & $\begin{array}{l}29.9 \\
\text { echo N }\end{array}$ & & & $\begin{array}{l}\text { 29.9, echo } \\
N\end{array}$ & & & & $\begin{array}{l}23.3, \\
\text { echo } \uparrow, \\
\text { volume } \\
\downarrow\end{array}$ & $\begin{array}{l}21.3, \\
\text { echo^, } \\
\text { volume } \downarrow\end{array}$ & & & $\begin{array}{l}14, \text { echo } \\
N_{1} \\
\text { volume } \downarrow\end{array}$ & \\
\hline $\begin{array}{l}\text { Left testis/ } \\
\mathrm{mm}^{3}\end{array}$ & & $\begin{array}{l}28.9 \\
\text { echo N }\end{array}$ & & & $\begin{array}{l}\text { 28.9, echo } \\
\mathrm{N}\end{array}$ & & & & $\begin{array}{l}16.4, \\
\text { echo } \uparrow, \\
\text { volume } \downarrow\end{array}$ & 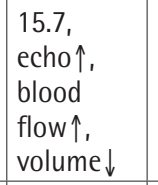 & & & $\begin{array}{l}12.2, \\
\text { still high } \\
\text { echo, } \\
\text { volume } \downarrow\end{array}$ & \\
\hline Varicocele & & $\begin{array}{l}2 \mathrm{~mm}, \\
\text { reflux } \\
(+)\end{array}$ & & & $\begin{array}{l}2 \mathrm{~mm} \\
\text { reflux (+) }\end{array}$ & & & & & $\begin{array}{l}2 \mathrm{~mm} \\
\text { reflux (+) }\end{array}$ & & & & \\
\hline Rigth W-B & 0 & 0 & 0 & 0 & 2 or 4 & 2 or 4 & 2 or 4 & 2 or 4 & 2 or 4 & 8 & 0 & & Absent & \\
\hline Left W-B & 0 & 0 & 0 & 0 & 4 & 4 & 4 & 4 & 4 & 10 & 0 & & 2 & \\
\hline $\begin{array}{l}\text { qRT-PCR for } \\
\text { COVID-19 }\end{array}$ & & & & Positive & & Negative & & & & Negative & & & & \\
\hline CRP mg/L & & & & & 5.62 & & & 9.77 & & 37.9 & 2.9 & & 0.1 & \\
\hline $\begin{array}{l}\text { ORP } / \mathrm{mV} / 10^{6} \\
\text { sperm/mL }\end{array}$ & & & 0.98 & & 3.76 & & 2.45 & & & & 1.89 & & 1.1 & \\
\hline $\begin{array}{l}\text { SDFI } \\
\text { (TUNEL) }\end{array}$ & 8 & & & & 22 & & 26 & & & & 11 & & 8 & \\
\hline ICSI & & & & & & & & & & & ICSI day & $\begin{array}{l}\text { Embryo } \\
\text { transfer }\end{array}$ & & \\
\hline $\begin{array}{l}\text { Time- } \\
\text { lapse/h, } \\
\text { division }\end{array}$ & & & & & & & & & & & & $42.9 \pm 27.88$ & & Pregnant \\
\hline $\begin{array}{l}\text { Complete } \\
\text { urine }\end{array}$ & & & & & $\mathrm{N}$ & & & & $N$ & $\mathrm{~N}$ & & & $N$ & \\
\hline $\begin{array}{l}\text { SPSS } 27.0 \\
\text { program }\end{array}$ & & & & & & & & & & & & & & \\
\hline \multicolumn{15}{|c|}{$\begin{array}{l}\text { COVID-19: Coronavirus disease-2019, FSH: Follicle-stimulating hormone, LH: Luteinizing hormone, T: Total testosterone, PRL: Prolactin, E2: Estradiol, LT: Liquefaction time, ICSI: Intracytoplasmic sperm injection, } \\
\text { TMSC: Total motile sperm count, Wong-Baker (W-B) Face pain rating scale; } 0 \text { no hurt, } 2 \text { hurts little bit, } 4 \text { hurts little more, } 6 \text { hurts even more, } 8 \text { hurts whole lot, } 10 \text { hurts worst, qRT-PCR: Quantitative reverse } \\
\text { transcriptase-polymerase chain reaction, CRP C-reactive protein, SDFI: Sperm DNA fragmentation, Time-lapse the system for monitoring early embryo morphokinetics development, B HCG shows pregnancy value in } \\
\text { blood. The embryo is checked on the } 12^{\text {th }} \text { day following the transfer. It indicates pregnancy between } 5-50 \mathrm{mIU} / \mathrm{mL} \text { in the first three weeks. TUNEL: The terminal deoxynucleotidyl transferase-mediated deoxyuridine } \\
\text { triphosphate-nick end labeling (TUNEL) assay, ORB: Oxidation-reduction potential (An ORB cut-off value of }<1.42 \mathrm{mV} / 106 \mathrm{sperm} / \mathrm{mL} \text { was regarded normal), N normal } \downarrow \text { decreased, } \uparrow \text { increased }\end{array}$} \\
\hline
\end{tabular}




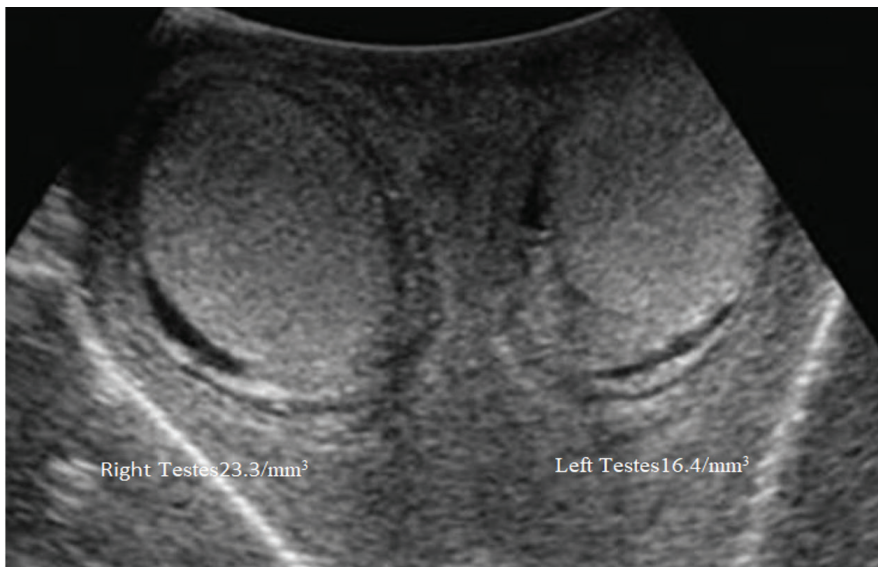

Figure 1. Testicles with elevated echogenicity on day 49 due to COVID-19 COVID-19: Coronavirus disease-2019

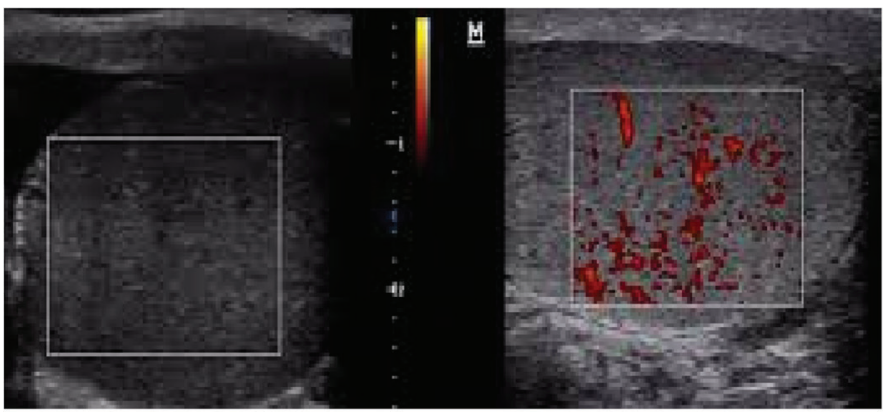

Figure 2. Elevated echogenicity in the right/left testes and elevated blood flow in the left testis under scrotal color Doppler on day 75 after COVID-19

COVID-19: Coronavirus disease-2019

epididymitis orchitis swelling was observed. The patient's white blood cell count was $(12.600 / \mu \mathrm{L})$ with lymphocytopenia $(724 / \mu \mathrm{L})$. A reduction in testicular volumes was noted in both testes and particularly in the left testis under Doppler. The echogenicity was elevated. The left testicular blood flow was observed to increase (Figure 2). The semen values were consistent with the levels before COVID-19 from days 45 to 108 . No changes occurred in the gonadotropic and prolactin values on days 46 to 90 before and after COVID-19; however, a decrease was observed in the total testosterone (TT) hypogonadism level on days 90 to 108. The patient had no pain in his right testis on day 108 during his follow-up, but the pain in his left testis persisted. A decrease was observed in the testicular volumes under ultrasound. His left testicular echogenicity was still elevated. The volume reduction in the right and left testes occurred as $15.9 / \mathrm{mm}^{3}\left(29.9 / 14 \mathrm{~mm}^{3}\right.$, $53.17 \%$ ) and $16.5 / \mathrm{mm}^{3}\left(28.7 / 12.2 \mathrm{~mm}^{3}, 57.78 \%\right)$, respectively from days 49 to 108 . Permanent losses were noted in rapidly progressive and in situ motile sperms in the semen analyses on day 108 (Table 1). An intracytoplasmic sperm injection (ICSI) was performed on day 90. Embryo transfer was carried out on day 95 and pregnancy was detected in the blood on day 113 . Ultrasonographic gestational sac and fetal pulses were observed on day 131 after COVID-19. A healthy pregnancy of 8 weeks is currently preserved. All chronological follow-up is presented in Table 1.

\section{Discussion}

It was claimed that SARS-CoV-2 causes spermatogonia and increases expression in Leydig and Sertoli cells with angiotensinconverting enzyme 2 receptors and triggers an autoimmune inflammatory response (4). Autoimmune orchitis disrupts the testicular-blood barrier $(3,4)$. This disrupts the balance of reactive oxygen species. The oxidative stress disrupts sperm morphology and acrosome structure and leads to damage in sperm deoxyribonucleic acid (DNA). Simultaneous elevation of oxidative reduction potential (ORP), CRP, and sperm DNA fragmentation index (SDFI) seemed to support COVID-19 autoimmune orchitis. Interestingly, normalization was observed in all three values towards day 108. We saw high-quality sperms with acrosome and high motility and cytoplasmic integrity, in which we detected the nuclei in intracytoplasmic morphologically selected sperm injection (IMSI). We observed embryo formations of 2PN (pronucleus) quality in our morphokinetic follow-ups in time-lapse on day 5. CRP elevations may negatively impact testicular functions and spermatogenetic activity (4). CRP elevation, severe orchialgia, and increase in testicular echogenicity were observed on days 66 to 75, whereas a volume reduction was noted in the testes compared to day 49 (Figure 1, 2). Even if the body temperature increases by one degree, the regulation of the scrotal temperature is disrupted. Thus, sperm count and/or motility is/are reduced (5). This leads to a modification in the sperm DNA integrity (5). A minimum of 3 months may be required to normalize these parameters (6). Therefore, assisted reproductive approaches are recommended to be postponed for at least 3 months in men who have COVID-19 with fever (6). COVID-19 was reported to promote the negative impact of testosterone (7). Severe scrotal pain, elevation in testicular echogenicity, reduction in their volume, and a $\Pi$ reduction signaling hypogonadism on days 90 through 108 were observed in our 3-month follow-up.

Despite being temporary, an elevation in CRP and ORP, high fever, and transiently rising SDFI levels were observed in the male patient with COVID-19. A severe reduction occurred in transient total sperm count, whereas a permanent reduction was noted in total motile sperm count levels. Testicular pain that developed after COVID-19 persisted for a long time. Most importantly, a permanent reduction occurred in testicular volumes. Highquality sperms were detected in IMSI. A high fertilization rate was achieved. Embryo morphokinetics was normal at timelapse. Despite debated changes associated with COVID-19 in a male patient with primary infertility, ICSI that was performed 3 months after the disease resulted in pregnancy. 


\section{Ethics}

Informed Consent: Consent was obtained from the patient to use the data.

Peer-review: Externally peer-reviewed.

\section{Authorship Contributions}

Concept: A.S., A.S.G., F.A., Design: A.S., Data Collection or Processing: A.S., F.A., Analysis or Interpretation: A.S., Literature Search: A.S., A.S.G., F.A., Writing: A.S.

Conflict of Interest: No conflict of interest was declared by the authors.

Financial Disclosure: The authors declared that this study received no financial support.

\section{References}

1. Xu J, Zhao S, Teng T, Abdalla AE, Zhu W, Xie L, Wang Y, Guo X. Systematic Comparison of Two Animal-to-Human Transmitted Human Coronaviruses: SARS-CoV-2 and SARS-CoV. Viruses 2020;12:244.
2. Xu J, Qi L, Chi X, Yang J, Wei X, Gong E, Peh S, Gu J. Orchitis: a complication of severe acute respiratory syndrome (SARS). Biol Reprod 2006;74:410-416.

3. Li N, Wang T, Han D. Structural, cellular and molecular aspects of immune privilege in the testis. Front Immunol 2012;3:152.

4. Feng Pan, Xingyuan Xiao, Jingtao Guo, Yarong Song, Honggang Li, Darshan $P$ Patel, et al. Effect of SARS-CoV-2 infection upon male gonadal function: a single center-based study. MedRxiv 2020.03.21.20037267.

5. Sergerie M, Mieusset R, Croute F, Daudin M, Bujan L. High risk of temporary alteration of semen parameters after recent acute febrile illness. Fertil Steril 2007;88:970.e1-7.

6. Carlsen $E_{1}$ Andersson AM, Petersen JH, Skakkebaek NE. History of febrile illness and variation in semen quality. Hum Reprod 2003;18:2089-2092.

7. Pozzilli $\mathrm{P}$, Lenzi A. Commentary: Testosterone, a key hormone in the context of COVID-19 pandemic. Metabolism: Clinical and Experimental 2020;108:154252. 